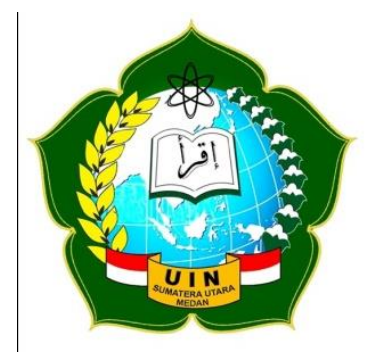

VISION JOURNAL

http://jurnaltarbiyah.uinsu.ac.id/vision

E-ISSN 2745-7982

\title{
IMPROVING THE STUDENTS' WRITING SKILLS OF NARRATIVE TEXT THROUGH BEYOND CENTERS AND CIRCLE TIME METHOD
}

\section{Deasy Yunita Siregar ${ }^{1}$, Fatma Wati Hasibuan²}

Email: deasyyunitasiregar@uinsu.ac.id, fatmawatihasibuan96@gmail.com

${ }^{1,2}$ Departement of English Education, State Islamic University of North Sumatera

\begin{tabular}{|c|c|}
\hline Keywords & Abstract \\
\hline $\begin{array}{l}\text { Keywords: writing skill, } \\
\text { narrative text, beyond centers } \\
\text { and circle time }\end{array}$ & $\begin{array}{l}\text { This research was aimed to improve the students' writing skill } \\
\text { of narrative text through beyond centers and circle time } \\
\text { method. The subjects of this study were } 25 \text { students at } 10 \text { th } \\
\text { grade in vacational high school MAS AL-HIDAYAH } \\
\text { academic year } 2018 / 2019 \text {. This research was conducted by } \\
\text { using classroom action research that consist of } 2 \text { cycles. The } \\
\text { technique of analyzing data for quantitative data was the } \\
\text { students' score of test. While for qualitative data, the } \\
\text { researcher used the technique by Miles and Huberman. The } \\
\text { result of this research showed that the mean of the students } \\
\text { score was } 54,72 \text { in which there were } 5 \text { from } 25 \text { students who } \\
\text { passed the standart minimum score or KKM. In the post test } \\
\text { I, there were } 10 \text { or } 20 \% \text { who improved and the score mean } \\
\text { was } 65,12 . \text { Meanwhile, in the post test II, the mean score was } \\
78,12 \text {. There were } 18 \text { students or } 72 \% \text { passed the standart } \\
\text { minimum score. It indicated that beyond centers and circle } \\
\text { time method could improve the students writing skill of } \\
\text { narrative text. This result was strengthened by the observation } \\
\text { and the interview result that students were more active in the } \\
\text { class and enjoy the learning process. They were also active in } \\
\text { learning proccess. }\end{array}$ \\
\hline
\end{tabular}

Faculty of Tarbiyah and Teacher Training, 1st Floor

Jalan Willem Iskandar Psr V Medan, 20731

Telp. 061- 6622925 - Fax. 061 - 6615685 


\section{INTRODUCTION}

Writing is one of the learning requirements for the student to be successful in their study. Writing as one of the four skills of listening, speaking, reading, and writing has always formed part of the syllabus in the teaching of English. It means that writing as a part of teaching English and important in teaching and learning English. Writing involves some language component (spelling, grammar, vocabulary, and punctuation). In writing skill, the student have to master vocabulary and know how to use grammar in making texts or sentences, it is an important skill because it will be applied in many aspect of life. Through writing, people are supposed to be able to express their ideas in writing form. There are many ways to express writing and one of them is through a text.

Based on the objective of teaching writing narrative text for vocational high school at grade $10^{\text {th }}$ is to produce in the written form of the various meaning of the text in a variety of interactional text and monologue primarily in the form of descriptive, spoof/recount, procedures, report, news item, anecdote, exposition, explanation, discussion, commentary, review, and narrative. In writing narrative text, the students are expected to be able to write the orientation, complication resolution and re-orientation.

Orientation is about the opening paragraph where the characters of the story are introduced. Complication is the main element of narrative. The complication is pushed along by a serious of event, during which usually expect some sort complicating or problem to arise. The conflict can be shown as natural social or psychological conflict. Resolution or coda is a closing remark to the story and it is optional. It consists of a moral lesson, advice or teaching from the writer.

Moreover, the reality of the student at $10^{\text {th }}$ grade Vocational High School MALUINSU were not able to write narrative text yet. It could be proven by the confusion that they got in writing narrative text. Such as they experiencing boredom in writing and they did not know yet how to write the orientation, complication, resolution and reorientation well. The student also were lack of motivation in studying, vocabularies mastery and among others. Besides that, the problem also come to the teacher that got difficulty in finding a good teaching method especially in writing method.

Based on the problem above, a teacher need to solve the students' problems in writing narrative text. To improve the student in writing skills the teachers are able to use some strategies. By using strategies it can improve the students' skill in learning process. In this case, the researcher will use beyond center and circle time strategy, because this strategy has many benefits, because this method have several advantages such as the process of learning is 
organized in the form of activities which aimed at students learning by experience so that then they study writing they have had a background knowledge about it. It could make the students easily to learn, consequently the, relieving stress due to the many learning burdens and increasing the focus on learning. Because of learning English especially writing, the students often feel bored and stressed. So, the students always experience a decrease in learning while in English class.

By this strategy, it makes students easier to learn, because in learning English especially writing narrative text students need calm and focus on learning. With this strategy consequently the students' writing will be better than before. Because the strategy emphasize on the students' activity and the teachers. As on the explanation above the researcher conducted a research under the topic 'Improving Students' Ability in Writing Narrative Text Through Beyond Center and Circle Time".

\section{LITERATURE REVIEW}

A skill comes from the word that means capable, and adept. According to Oxford learner's pocket dictionary $4^{\text {th }}$ editions, capable is defined as having ability to do things well while adept as very skilled or proficient at something. Iverson (1983) stated that a skill needs training and basic capabilities that be owned by everyone that can help to create something more value and faster. In this case the skills are divided into 4 categories, namely: (1) Basic Literacy Skill: is the basic capabilities which will surely have to be owned by everyone such as reading, speaking, listen, and writing, (2) Techinical skill: is the skill technically through learning in engineering such as operating computers and other digital tools, (3) Interpersonal Skill: is the skill of everyone in conducting of communication each other like listening to someone, giving opinions and working in a team, (4) Problem Solving: is the skill of everyone in solving the problem.

According to Soemarjadi (1992), a skill has the same meaning with the word of adept. Skilled or adept is cleverness to do something quickly and correctly. Soemarjadi (1992) also stated that someone who can do something quickly but wrong cannot be said to be skilled. Similarly, if someone can do anything right but slow, also cannot be said to be skilled. While the scope of the skill itself is quite extensive, including activities in the form of, thinking, speaking, seeing, writing and listening. In learning, skills is designed as a process of communication learning to change the behavior of students become quick and accurate in doing or face something 
Hasan (1995:260) argued that a skill is the competence in doing something. Skill shows a performance that can be done right now. Accoording to Bernardin and Russel (in Rucky, 2005), performance is defined as the record of outcomes produced on a specified job function or activity during time period. Bernardin and Russel (1993) stated that a performance that can be done in future need talent and skill. Talent and skill determine the achievement of the students. Students may have talent in chemistry that is considered to obtain the achievement. So, the best achievement comes from the talent and skill of someone (Harmer, 2005).

Then, a skill is a performance that be got by someone from training and experiencing. So he/she can do something correctly, accurately and quickly. While writing is one of the four language skills besides listening, speaking and reading. It is an activity in arranging words, phrases, and sentences that is grammatically correct and appropriate with its purpose. According to Harmer (2005), writing is a way to produce language and express idea, feeling and opinion. Furthermore he stated that writing is a process that what people write is often heavily influenced by the constraints of genres, and then these elements have to present in learning activities. Harmer (2005) also stated that there are four element in process writing, those are; (1) Planning: the writer has to think about the issue, (2) Drafting; one can refer to the first version of a piece of writing as a draft. A number of drafts may be produced on the way to the final version, (3) Editing; after writers produce a draft, then they usually read what the result of the draft is in order to see where it works and where it doesn not work, and (4) Final report; the writer now ready to send the written text to intended audience.

Meyers (2005) stated that writing is a way to produce language you do naturally when you write. Writing is speaking to other on paper- or on computer screen. Writing is also an action a process of discovering and organizing your ideas, putting them on a paper and reshaping and revising them. He states that there are 6 steps to make a good writing, namely: (1) Exploring ides: it involves discovering idea such as subject, purpose, audience, (2) Prewriting: This process involves writing your though on paper, (3) Organizing: this process involves selecting, subtracting, and adding, (4) Writing the first draft, (5) Revising the draft: it means improving what you have already written and, (6) Producing the final copy: It consist of editing, proofreading.

According to Dewi (2011), writing is the expression of language in the form of letters, symbols, or words. The primary purpose of writing is communication. People have used many tools for writing including paint, pencils, pens, typewriters, and computers. The witing 
can be formed on the wall of cave, a piece of paper, or a computer screen. The are many kinds of writing such as expository, narrative, descriptive, and persuasive (Dewi, 2011).

Narrative is the telling of a story the succession of event is given in chronological order social function; to amuse, entertain, and to deal with actual or various experience in different ways (Yanpitherszon, 2017). According to Pardiyono (2007), narrative text is a kind of text that exactly to tell the activities or events in the past, that show problematic experience and resolution means to amuse oftentimes meant to give moral lesson to the readers. The generic structure of narrative text are as follows: (1) Orientation; sets the scene and introduces the participants, (2) Evaluation; a stepping back evaluate the plight, (3) Compilation; a crisis arises, (4) Resolution; the crises is revolves, for better or for worse, and (5) Re-orientation; optional (Purba, 2018).

According to Pardiyono (2007), narrative is a story talk the past activities or events which order to problematic and to give lesson to readers". To write the narrative, there are four components that shall be care: (1) Orientation; it is parts of text give setting or opening about narrative, (2) Complication; it is parts of text to inform about the conflict in narrative, (3) Resolution; it is parts of text to describe about the reaction to solve the problem, (4) Coda, it is the describe reflection or evaluation the conflict about narrative.

Moreover, narrative text is a text, which related a serried of logically and chronologically related events that are caused or experienced by factors. A key of comprehending narrative is a sense of plot, them, characters, events, and how they relate. The social functions of narrative text are to amuse, entertain and deal with actual and vicarious experience. The generic structure of this text is orientation, evaluation, complication, resolution and reorientation. Orientation sets the scene and introduces the participants involved in the text. Evaluation is stepping back to evaluate the plight. Complication happens when a crisis rises. Resolution is when the crisis resolved for better or for worse. In addition, reorientation is an optional one that contain writer's opinion or conclusion. (Herlina, 2012).

Based on the study of BBTC method, it can improve the student' writing skill because this method make the students learn by experience, discussion and students center and that has been described in the effects of teaching and learning is a process of communication between teachers and students. The teacher must create communication to make it easier for students to receive the knowledge conveyed by the teacher. However, in reality teaching and learning activities are not as desired. The teacher still uses a boring method, so students cannot receive the information or knowledge conveyed by the teacher. In addition, students 
also do not have the opportunity to be active in learning activities, and consequently the activities of student learning outcomes are low.

To create an effective learning process, teachers are expected to be able to use the right strategies. The right strategy is expected to increase activity and creativity in the learning process, and also to avoid students from feeling bored during the learning process. Students who feel happy during the learning process will be more active, this can also improve learning outcomes from students, so that the learning process becomes easier the teacher can use a fun method of dividing students into groups to help students who are difficult to communicate. This method makes the student to have a group discussion so that make them to be able to discuss the material together and make to be active in learning.

The method emphasize on the students' learning center. By students learning center, the students will do many activities and more active that the teacher. Besides that, learning process will be interesting because this method use many center of study. The center of study consist of four center, they are orientation center, complication center, resolution center, and re-orientation center.

In the orientation center the student will discuss about the opening of paragraph where the character of the story are introduced. In the complication, the student will discuss the conflict that appear in the story. In resolution, the student discuss the problem solving in the story and the re-orientation center the students will discuss about the closing remark of the story such as moral lesson, advice or teaching from the writer.

\section{METHOD}

The aim of the research was improve the students' writing skills in narrative texts. So, this research can be categorized into classroom action research study. According to Arikunto (2006), classroom action research is a form of accurate learning activity against an act, deliberately raised and occur in a class together. Moreoer, Arikunto (2006) stated that action research is a research in which the purpose is to evaluate and then to change something in order to improve the educational practice. Action research is also a form of inquiry undertaken by participants in social situations in order to improve both social and educational practice, as well as the understanding of these practices and the situations in which practice is carried out, The essential characteristics of action research can be summarized as follows (Koshy, 2005 and Bassey, 1998):

1. Action research is contextual, small-scale and localized. It identifies and investigates issues within a specific situation. 
2. Action research is evaluative and reflective as it aims to bring about change and improvement in practice.

3. Action research is participatory as it provides for collaborative investigation by teams of colleagues, practitioners, and researchers.

4. Change in practice are based on the collection of information or data which provides the impetus for change.

The research of the study is conducted by administrating four meeting and two cycles. Each cycle consists of three meeting and consists of four steps, namely planning, action, observation and reflection. (Harmer and Jeremy, 2007).

\section{Planning}

In this stage, the results of the observation and interview are used as reference. Based on that data, the researcher started to prepare all of the actions and the materials for teaching writing on narrative text by using picture series. The preparation covered preparing the lesson plan, preparing the materials, preparing the media, and also preparing the scoring rubric and other instruments.

\section{Action}

After making some plans, picture series are implemented as the main media to teach writing for a certain period of time. The research was done in two cycles. Every cycle is done in 3 meetings. In every meeting, the researcher implemented the use of picture series to guide the students' to be able to write the text. Furthermore, different techniques and activities are also applied to teach the students' in order to make the teaching and learning interesting. Those activities are sequencing jumbled pictures, jumbled paragraphs, and filling in the blank.

\section{Observation}

During the action, the researcher will observe the teaching and learning process including the students' writing. The things to be focused on this stage are observing the effectiveness of using picture series, the students' behavior in the class, and their writing products. 


\section{Reflection}

The researcher made a reflection and e valuated the actions that are carried out. The focus this on the implementation of picture series in teaching writing whether it this successful or not. If it had not been successful yet, another cycle should be continued. Finally, by analyzing the data from the qualitative and quantitative data, the researcher can make a conclusion whether picture series can improve students' writing skill or not.

\section{FINDING AND DISCUSSION}

The research was conducted to find out the improving of students' writing descriptive text through beyond centers and circle time method. This method was one of many steps can be used by the researcher in teaching English especially to help the students to improve the writing skill.

According to Siantayani (2005:6) BCCT method is a method in education that focus onstudents-centered in the corners is used for teaching and learning process where a student is able to discuss in order to increase their skill and knowledge. In this case, the students have more time to learn. Besides, they can learn something, they can make association with others.

By using Beyond Center and Circle Time method may certainly be an effective way for students in teaching-learning English. Through experience and students center the teachers did not necessary to teach longer because the students have had a background of knowledge and did many activities in process of learning.

The researchers have done some steps in the first cycle. They were planning, action, observation, and reflecting. The observation was done in the second cycle. All the activities during the teaching learning process had been observed. They were as follow: 1). Most of the students were motivated, enthusiastic and interested in learning process, 2). Many students thought that the beyond centers and circle time method more effective in improving the students' writing skills of narrative text, 3). The mean score was categorized success, 78,12.

In this phase, the result of observation were collected by the qualitative, researchers gave them the post test in the second cycle. The result of the post test showed that the total score of the students was 1.953 and the students' mean was 78,12. The percentage of the students' score was $72 \%$ consisted of 18 students were successes and achieved score $75 \%$ or up. So, the posttest in second cycle was categorized successful. Based on the data above, the result showed the improvement of the students' score from the pre-test to the post-test I and post-test II. In the pre-test, the students who got the score of 75 was 5 from 25 students 
(20\%). In the post-test the researchers who got the score of 75 or up was 10 students $(40 \%)$ and the post-test II who got the score of 75 was 18 students (72\%). It means that that was improvement about 20\%. In the third test there was $72 \%$ (18 students) who got the score 75 or more. There was improvement about $32 \%$ from the second test, and about $52 \%$ from the first test to third test. Most of students' score improved from the first to the third test.

\section{Diagram 1.1}

\section{The Percentage of Students}

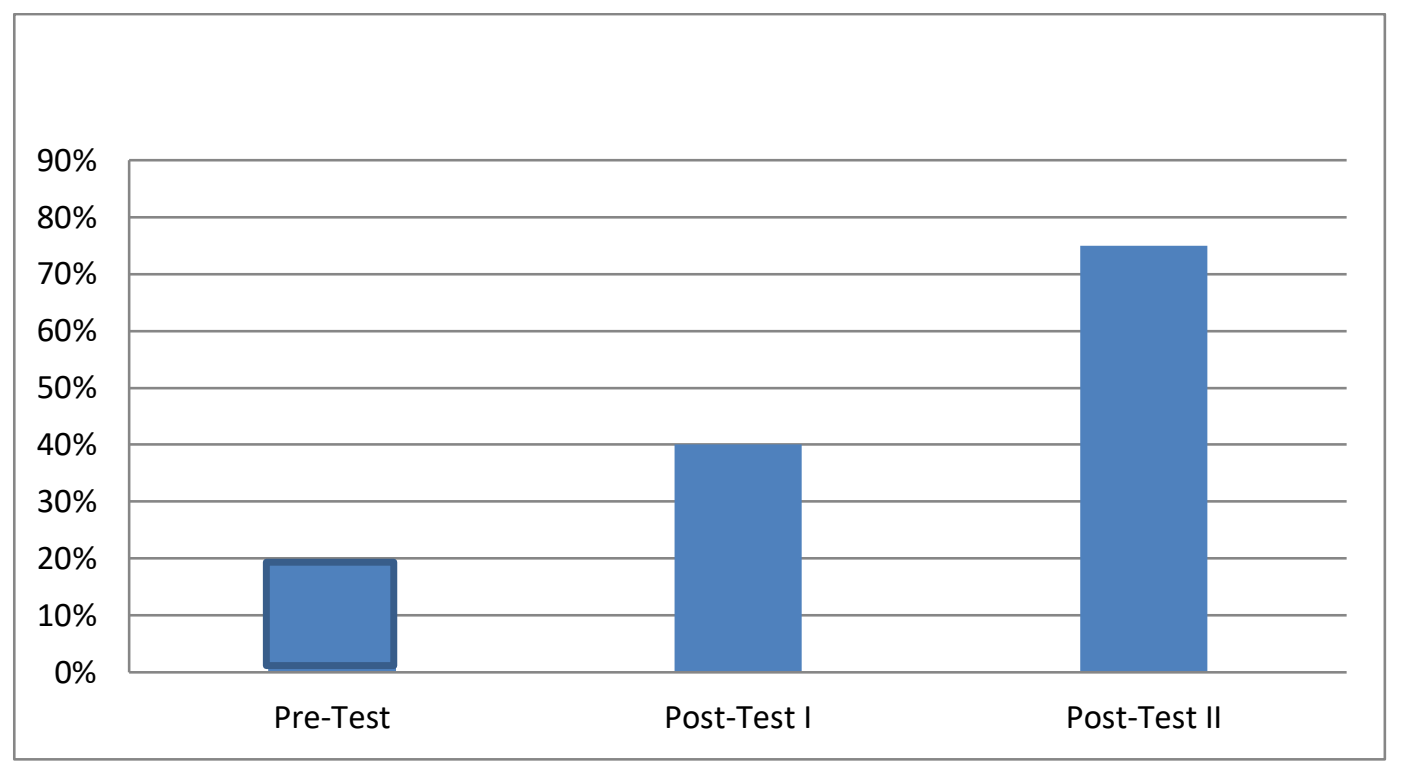

In this research, it also used the hypothesis test from the compilation, it could be seen that the coefficient of $\mathrm{t}$-observed and $\mathrm{t}$-table to $\mathrm{df}=\mathrm{N}-1=25-1=24$, with fact $\alpha=0.05$ was 0,515 in the coefficient of t-observed (10.29) > t-table $(0,515)$. Thus, alternative hypothesis $\left(\mathrm{H}_{\mathrm{a}}\right)$ can be received. Based on finding, alternative hypothesis $\left(\mathrm{H}_{\mathrm{a}}\right)$ stated that beyond center and circle time method could improve the students' writing skills of narrative text.

It could be proven from the result of observation that the researcher could active the students in learning. It made the students' score improved and achieved the target (KKM). It indicated that the implementation of beyond center and circle time method can help the students in writing narrative text.

From the explanation above, the research could be concluded that the implementation of beyond centers and circle time method can improve the students' writing skill. It could be seen from the quantitative data which the students' score got better in every test: pre-test, post test I, and post test II. And also it could be showed by the qualitative data which prove the researcher could control the class and the students were active and interested in learning English and easy to write the narrative text. 


\section{CONCLUSION}

The result of preliminary study shows that skills of students in writing narrative text was low, they get confusion in write narrative text. The number of students who followed the test was 25 students. The result of pre-test, the total score of the students was 1.368 and the mean of students' score was 54,72 and the percentage was $20 \%$ or only 5 students who successed or got score up 75. On the other hand, 25 students were not success or did not get score up to 75. It means that the students' writing skill were low. Therefore I would like to improve the students' writing skill through beyond centers and circle time method.

In the cycle I, the result of observation were collected to get the qualitative data, based on the data observation, there was improvement in teaching learning process but still low. It can be seen from the hypothesis of the research from compilation of pre-test and posttest I wasdf $=\mathrm{N}-1=25-1=24$, with fact $\alpha=0.05$ was 0,515 in the coefficient of $t$-count $(6,03)>t$ table $(0,515)$. Thus, alternative hypothesis $\left(\mathrm{H}_{\mathrm{a}}\right)$ cannot be received. Based on finding, alternative hypothesis $\left(\mathrm{H}_{\mathrm{a}}\right)$ stated that beyond center and circle time method already increased the students' writing skill of narrative text but not significant yet.

In the cyle II, the students were motivated, participated and enthusiastic in learning writing narrative text. It could be seen from the result of interview and observation. while the hypotesis post -1 and post -2 was $\mathrm{df}=\mathrm{N}-1=25-1=24$, with fact $\alpha=0.05$ was 0,515 in the coefficient of t-count (10.29)> t-table $(0,515)$. Thus, alternative hypothesis $\left(\mathrm{H}_{\mathrm{a}}\right)$ can be received. Based on finding, alternative hypothesis $\left(\mathrm{H}_{\mathrm{a}}\right)$ stated that beyond center and circle time method could improve the students' writing skills of narrative tex and significant. So, the posttest II was categorized successful. Finally, the researchers have done two cycles because the researchers had solved the problems which found problem during teaching learning process.

\section{REFERENCE}

Alan, Evison. (1983). Oxford Learner's Pocket Dictionary Fourth Edition Oxford University Press

Arikunto, Suharsimi. 2006. Class Room Action Researceh. PT Bumi Aksara.

Bassey, M. (1998). Action research \& school improvwmwnt: Ovening Doors from the Inside, (93). Buckingham: Oven University press.

Bernardin, H.J. \& Russel, J.E.A (1993). Human Resource Management an experiental approach. Singapore: Mc Graw-hill Inc. New York 
Dewi, Utami. 2011. How to write, Medan: La - Tansa press.

Hasan, Chalijah. (1999). Dimensi-DimensiPsikologiPendidikan. Surabaya: Al-Ikhlas.

Herlina. (1). DEVELOPING READING NARRATIVE TEXT MATERIALS FOR EIGHTH GRADERS OF JUNIOR HIGH SCHOOL IMPLEMENTED WITH CHARACTER BUILDING. English Education Journal, 2(2)

Jeremy Hermer. (2005). The Practice of English Language Teaching. Harlow: Longman.

Koshy, Valsa. 2005. Action Researc For improving Practice. London: paul Chapman Publishing

Meyers, Allan. 2005. Gateways to Academic Writing: Effective Sentences Paragraph and Essay. New York: Longman.

Pardiyono, 2007. Teaching Genre-Based Writing. Yogyakarta: AndiOffiset.

Purba, R. (2018). Improving the achievement on writing narrative text through discussion starter story technique. Advances in Language and Literary studies, 9(1), 27-30.

Rucky. (2013). SistemManajemenKinerja. Jakarta: PT GramediaPustakaUtama.

Soemarjadi, D. (1992). Education Skill. Jakarta: DEPDIKBUD

Yanpitherszon, L. (2017). THE STUDENTS'COMPETENCE IN UNDERSTANDING NARRATIVE READING TEXT AT SMAN 1 SOE KABUPATEN TIMUR TENGAH SELATAN (TTS) NUSA TENGGARA TIMUR. IDEAS: Journal on English Language Teaching and Learning, Linguistics and Literature, 5(1). 